\title{
THE APPLICATION OF ISLAMIC SPIRITUAL METHODS IN NURSING PROGRAM CURRICULUM AT UIN SYARIF HIDAYATULLAH JAKARTA AND UIN ALAUDDIN MAKASAR
}

\author{
Dwi Setiowati ${ }^{*}$, Peggy Rianti Kurnia Sukma ${ }^{2}$, Rasdiyana Rahim ${ }^{3}$ \\ ${ }^{1}$ UIN Syarif Hidayatullah Jakarta, Indonesia, email:dwi.setiowati@,uinjk.t.ac.id \\ ${ }^{2}$ UIN Syarif Hidayatullah Jakarta, Indonesia, email: peggy.riyanti17@mbswa.uinjkt.ac.id \\ ${ }^{3}$ UIN Alaudin Makassar, North Sulawesi, Indonesia, email: rasdiyanah.ners@uin-alauddin.ac.id \\ *Corresponding Authors \\ cc) (i) (2)
}

(C)2021 by the authors. Submitted for possible open access publication under the terms and conditions of the Creative Commons Attribution-ShareAlike 4.0 International License-(CC-BY-SA) (https://creativecommons.org/licenses/by-sa/4.0/) doi DOI : bttp://dx.doi.org/10.30983/it.v5i2.4933

\begin{tabular}{|l|l|l} 
Submission: 21 October 2021 & Revised: 01 December 2021 & Published: 31 December 2021
\end{tabular}

\section{Abstract}

This research focuses on describing the implementation of Islamic spiritual care of the clinical nursing students at the State Islamic University (UIN). The implementation of Islamic spiritual care has not been done well by nurses. Clinical nursing students are the forerunners of nurses, but no one has examined the description of the application of Islamic spiritual care carried out by clinical nursing students in State Islamic University (UIN). This research method was descriptive quantitative. Samples were students of the clinical nursing students of UIN Jakarta and UIN Alauddin Makassar, 40 respondents. The results showed that most respondents applied Islamic spiritual care well (52.5\%). The most well-implemented component is instilling optimism for healing that comes from God $(60 \%)$. Students need to improve their selfcompetence in Islamic religious knowledge to become more competent in providing Islamic care to patients. The head of the clinical nursing program needs to emphasize efforts to increase Islamic spiritual competence in the clinical practice setting of learning guidelines through the guidance process and learning achievement targets.

Keywords: Islamic spiritual method, Nursing program, Curriculum

\section{Abstrak}

Penelitian ini berfokus untuk mengetabui penerapan perawatan spiritual Islam mabasiswa Ners di Universitas Islam Negeri (UIN). Penerapan asuban keperawatan secara bolistik. khususnya dalam aspek spiritual karena masih sangat minim dilakukan oleh perawat di tatanan pelayanan keperawatan. Mahasiswa merupakan cikal bakal perawat dan peneliti belum menemukan penelitian tentang penerapan perawatan Islam oleh mahasiswa Ners di lingkungan UIN. Metode yang digunakan yaitu deskriptif kuantitatif. Sampel yang digunakan yaitu mahasiswa Ners UIN Jakarta dan UIN Makassar masing-masing 40 responden. Hasil menunjukekan sebagian responden menerapkan perawatan spiritual Islam dengan baik (52,5\%). Komponen yang paling banyak diterapkan dengan baik yaitu menanamkan optimisme kesembuban yang datang dari Allah (60\%). Mahasiswa perlu meningkatkan kompetensi diri dalam ilmu agama islam sehingga menjadi lebih kompeten dalam mebrikan perawatah islam kepada paeien, program studi Ners perlu lebih menekankan pada upaya peningkatan kompetensi spiritual islam pada tatanan praktik. klini pedoman pembelajaran, melalui proses bimbingan maupu target capaian pembelajaran.

Kata Kunci: Metode spiritual Islam, Program Ners, Kurikulum

\section{Background}

Humans are holistic beings, consisting of several aspects, namely biological, psychological, sociological, spiritual, and cultural. Likewise, health services in the world must provide holistic services to patients because the patient's health is not only seen from the biological perspective, but must be fulfilled holistically. One of the important aspects of supporting

1 Saharuddin, Safrullah Amir, dan Rosmina, Spiritual di Rumah Sakit Islam Faisal Makassar," Hospital "Penerapan Pelayanan Model Keperawatan Berbasis Majapabit 10, no. 1 (2018): 28-33. Spiritual Ditinjau dari Aspek Proses Asuhan Keperawatan 
patients' healing in the world of health is the spiritual aspect. Wardah ${ }^{2}$ explained that spirituality helps patients adapt and cope with their illness and contribute to healing, especially for patients with terminal illnesses or critical conditions. In addition, in Anisa's research, spirituality improves a person's quality of life, makes life seems more meaningful, and can feel positive things from the activities carried out ${ }^{3}$.

The application of holistic nursing care, especially in the spiritual aspect, is minimal because nursing services are more focused on biological aspects. It happens because the disease seen and complained of by the patient is only a biological disease. However, these biological diseases can affect psychological, sociological, and spiritual aspects. If only treatment is carried out on biological aspects, other not handled aspects are feared to cause new problems. Wardah ${ }^{4}$ also explained that there are still many nurses who have not implemented nursing care in meeting the spiritual needs of patients.

Patients who are sick, especially those with chronic diseases, can experience spiritual distress. Spiritual distress is a disturbance in beliefs or value systems in the form of difficulty understanding the meaning and purpose of life, both relationships with oneself, others, the environment, and God. ${ }^{5}$ In the patient's condition, the importance of the participation of health workers, especially nurses and nursing students, is to provide explanations and reinforcement to patients. However, because it only focuses on the biological aspect, this spiritual aspect has been transferred to the clergy $^{6}$. Although the clergy is an expert and has adequate knowledge in the spiritual and religious fields, health workers, especially nurses, accompany patients for 24 hours. It is also essential for nurses to be able to handle the spiritual aspects of patients.

The American Association of Colleges of Nurses (AACN) requires nurses to be able to assess the spiritual needs of patients and recognize the importance of spiritual aspects to health care ${ }^{7}$. However, on the one hand, the level of application of spiritual care carried out by nurses is still low. ${ }^{8}$ explained in his research that the factors that can influence the application of spiritual care are nurse knowledge, nurse communication, nurse attitudes, and nurse culture. Pesut ${ }^{9}$ explained that there are three factors related to the difficulty of applying the spiritual aspect, namely every individual has spirituality, spiritual nursing is ethics and responsibility in holistic nursing, and some nurses are not ready to provide spiritual care, this is a weakness and negligence in the area of nursing practice. The application of spiritual care is also carried out by nursing students (Ners) practicing on patients. Nurse education programs are commonly referred to as clinical learning processes; students carry out professional education in practical fields such as hospitals, health centers, maternity clinics,
2 Wardah, Rizka Febtriana, dan Eka Dewi, "Pengaruh Pengetahuan Perawat Terhadap Pemenuhan Perawatan Spiritual Pasien di Ruang Intensif," Jurnal Endurance 2, no. October (2017): 436-43.

3 Elsa Annisa, Herman, dan Yoga Pramana, "Kebutuhan Spiritual dengan Kulitas Hidup Pada Lanjut Usia : Literature Review," Jurnal ProNers, no. July (2021): $1-12$.

4 Wardah, Febtriana, dan Dewi, "Pengaruh Pengetahuan Perawat terhadap Pemenuhan Perawatan Spiritual Pasien di Ruang Intensif."

5 PPNI, Standar Diagnosa Keperawatan Indonesia: Definisi dan Indikator Diagnostik, 2016.
6 Reza Ahmadiansah, "Model Dakwah dalam Pelayanan Pasien," IJIP: Indonesian Journal of Islamic Psychology 1, no. 2 (2019): 215-42, https://doi.org/10.18326/ijip.v1i2.215-242.

7 Barbara L Yoost dan Lynne R Crawford, Fundamental of Nursing: Active Learning for Collaboratibe Practice (St. Louis Missouri: Elsevier, 2016), 414-416.

${ }^{8}$ Reni Febrianti, Yulastri Arif, dan Mira Susanti, "Faktor yang Mempengaruhi Peran Perawat dalam Memenuhi Kebutuhan Spiritual Klien," Jurnal Ilmiah Ilmu Kesehatan 6, no. 1 (2020): 282-90.

${ }^{9}$ Pesut, Barbaba. Spirituality and Spiritual Care in Nursing Fundamentals Textbooks. J Nurs Educ. 47, no.4 (2008):167-73. doi: 10.3928/01484834-20080401-05. https://pubmed.ncbi.nlm.nih.gov/18468293/. 
nursing homes, and families and communities or communities. However, Azzahra ${ }^{10}$ said that the application of spiritual care is also carried out by nursing students (Ners) who are practicing on patients. Nurse education programs are commonly referred to as clinical learning processes, students carry out professional education in practical fields such as hospitals, health centers, maternity clinics, nursing homes, and families and communities or communities. ${ }^{11}$ explained the lack of perception and application of spiritual care by nursing students due to the lack of support from educational institutions to conduct learning about spiritual care, either on campus or during clinical practice.

There are several factors that influence the application of Islamic spiritual care include patient characteristics, the time required to build a trusting relationship with patients, nurse readiness, Islamic educational background undertaken by nurses, nurses' background knowledge on bio-psycho-socio-spiritual fulfillment of patients, the culture that adopted by patients and nurses, habits that patients and nurses often carry out, and the environment around the patient. The significant influence that occurs after the patient is applied to Islamic spiritual care is that the patient becomes more open to the nurse, the patient becomes calm, the patient complains less, such as when he feels pain, and the patient becomes routine in acting without being asked or recommended.

The Nursing Science Curriculum compiled by AIPNI (2016) spiritual care is still combined with other courses, and there is only one particular spiritual course, called the religion course, with a total of 2 credits. It illustrates no balance between the knowledge or knowledge learned by nursing students and nurses to

${ }^{10}$ Meza Belindiani Azzahra, Aan Nur, dan Cecep Eli Kosasih, "Persepsi Mahasiswa Keperawatan tentang Perawatan Spiritual (Spiritual Care) Perception of Nursing Students on Spiritual Care," Nursing Care \& Biomelecular 3, no. 2 (2018): 94-103.

11 Linda Ross Dkk., "Nursing and Midwifery Students' Perceptions of Spirituality, Spiritual Care, and achieve spiritual care. There are universities or health colleges in Indonesia based on religion, especially Islam. One of them is the State Islamic University (UIN), where UIN has a vision based on Islamic values. In the UIN Nursing Study Program, there are particular subjects that discuss Islamic or Spiritual Islam such as Islamic Nursing, Worship Practicum, Qiroah Practicum, Islamic Studies, Arabic, Islam and Science, and nursing courses with learning outcomes, one of which is the application of Islamic values in nursing care, this is a form of integration of Islamic values and Nursing Science.

Purwaningsih ${ }^{12}$ explained that the level of education influences the level of knowledge because the broader knowledge of nurses is associated with higher levels of care and impacts the completion of their responsibilities properly. So, it can be said that Islamic University students apply good spiritual care because these educational institutions provide courses that can support knowledge in applying Islamic spiritual care.

Based on the research above, the researchers have not found any specific research on applying Islamic care using Islamic spiritual methods to nursing students. teaching nursing at the academic and professional levels.

This research uses descriptive quantitative research with student respondents who follow the nursing profession at UIN Jakarta and UIN Makassar. A preliminary study was carried out in February 2021 on six nurses students using online interview methods through the WhatsApp application. Students' perceptions are good about applying Islamic care to patients; for example, respondents answered that Islamic spiritual care must be explored to help the

\footnotetext{
Spiritual Care Competency: A Prospective, Longitudinal, Correlational European Study," Nurse Education Today 67, no. April (2018): Https://Doi.Org/10.1016/J.Nedt.2018.05.002.

12 Diah Fitri Purwaningsih, "Perilaku Caring Perawat di Ruang Rawat Inap," Jurnal Ilmiab Kesehatan 3, no. 2 (2018): 61-67.
} 
patient's spiritual care needs, obstacles, and implementation. How to apply Islamic spiritual care to patients, namely by saying greetings before meeting the patient, reading basmalah before the action, reading hamdalah after the action, reminding prayer times, encouraging patients to do dhikr as self-relaxation, encouraging patients to do deep breathing techniques, reduce pain by listening to muratal and remembrance, and provide support to the patient's family. However, based on the evaluation from the hospital, most of the students were not confident in performing Islamic treatments on patients.

Thus, based on some of the explanations that have been described, this article focuses on explaining the application of Islamic care with the Islamic spirituality method in the curriculum of nursing professional study program students at 2 State Islamic Universities (UIN)".

\section{Respondent Characteristic}

Characteristics of respondents include gender, history of Islamic education at the high school level, ethnicity. The results show that in Table 1 some of the respondents are female as many as 62 respondents $(77.5 \%)$. Most of the last education was high school as many as 57 respondents $(71.3 \%)$. The Bugis ethnicity constitutes most of the respondents' ethnic groups as many as 22 respondents $(27.5 \%)$.

Gender

The gender of the respondents in this study consisted of 18 men and 62 women, so that the majority of respondents in this study were women as many as 62 respondents $(77.5 \%)$ as stated in the table below
Tabel 1. Frequency Distribution of Respondents

\begin{tabular}{|c|c|c|c|}
\hline No & $\begin{array}{c}\text { Characteristics of } \\
\text { Respondents }\end{array}$ & Frequency & Percentage \\
\hline \multirow[t]{3}{*}{1.} & Gender & & \\
\hline & Male & 18 & $22,5 \%$ \\
\hline & Female & 62 & $77,5 \%$ \\
\hline \multirow[t]{4}{*}{2.} & $\begin{array}{lr}\text { Last high } & \text { school } \\
\text { education } & \text { or } \\
\text { equivalent } & \end{array}$ & & \\
\hline & $\begin{array}{l}\text { Senior High School } \\
\text { or Vocational High } \\
\text { School }\end{array}$ & 57 & $71,3 \%$ \\
\hline & $\begin{array}{c}\text { Madrasah } \\
\text { Aliyah (MA) }\end{array}$ & 13 & $16,3 \%$ \\
\hline & Pesantren & 10 & $12,5 \%$ \\
\hline \multirow[t]{14}{*}{3.} & Ethnic Group & & \\
\hline & & 1 & $1,3 \%$ \\
\hline & Aceh & 2 & $2,5 \%$ \\
\hline & Padang & 2 & $2,5 \%$ \\
\hline & Lampung & 5 & $6,3 \%$ \\
\hline & Betawi & 12 & $15 \%$ \\
\hline & Jawa & 14 & $17,5 \%$ \\
\hline & Sunda & 1 & $1,3 \%$ \\
\hline & Madura & 1 & $1,3 \%$ \\
\hline & Dayak & 1 & $1,3 \%$ \\
\hline & Melayu & 18 & $22,5 \%$ \\
\hline & Makassar & 22 & $27,5 \%$ \\
\hline & Bugis & 1 & $1,3 \%$ \\
\hline & Buton & & \\
\hline
\end{tabular}

The results from table 1 above are supported by research conducted by Bawelle regarding the dominance of women in nursing where the number of female nurses is more than male nurses (95.4\%); this is supported by the theory regarding nurses whom women dominate because historically, Nursing emerged as the role of caretaking (caregiver) which is attached to a woman traditionally both in the family and in the community. Anggoro ${ }^{13}$ in his research explains that women are the majority of the gender who choose to work as nurses because, according to their abilities having higher social sensitivity than men, especially being a nurse, means having high social sensitivity so that nurses create caring actions.

Data available in the Ministry of Health ${ }^{14}$ explained that based on reports of membership in the Nursing Professional Organization
13 Wisnu Tri Anggoro, Qurrotul Aeni, dan Istioningsih Istioningsih, "Hubungan Karakteristik Perawat Dengan Perilaku Caring," Jurnal Keperawatan Jiwa 6, no. 2 (2019): https://doi.org/10.26714/jkj.6.2.2018.98-105.
${ }^{14}$ Kementerian Kesehatan RI, "Situasi Tenaga Keperawatan Indonesia," Pusat Data dan Informasi Kementerian Kesehatan RI, 2017: 5 . https://pusdatin.kemkes.go.id/folder/view/01/structur e-publikasi-pusdatin-info-datin.html. 
(PPNI) there were 256, 326 women (71\%) female nurses compared to only 103,013 male nurses $(29 \%)$. In the Ministry of $\mathrm{PPA}^{15}$ explained that the professional work undertaken by women was as a teacher and nurse. So it can be concluded that this study is in accordance with research and other reliable data that women are the majority of the gender who work as nurses and nursing students, including professional nursing students.

\section{Educational background}

In this study, the education level of the respondents was at the secondary education level, but came from various types of educational institutions. The type of secondary education of the highest respondents came from SMA or SMK General as many as 57 respondents $(71.3 \%)$, this is supported by the research of Hendri ${ }^{16}$ that the Department of Nursing or majors in the health sector are more in demand by students from public high schools, especially the science majors and general vocational schools, especially the health department, this is because at the high school level, students already have quite a lot of experience in subjects such as biology, chemistry, Physics which is usually re-studied in the realm of Nursing and other health fields, as well as General Vocational Schools, especially Health Vocational Schools which clearly have experience related to health both in terms of knowledge and in terms of practice.

\section{Ethnic group}

Indonesia is known to have many tribes in each region. In this study, the respondents consisted of 12 (twelve) ethnic groups, namely Aceh, Padang, Lampung, Betawi, Javanese, Sundanese, Madurese, Dayak, Malay, Makassarese, Bugis and Buton. The most widely adopted ethnic group is the Bugis, 22 respondents $(27.5 \%)$. Tribes are closely related to the existing culture and differ in each tribe. In research conducted by Ikhsan ${ }^{17}$ explains that the influence of ethnicity is very large on the continuity of the approach. Parawansah ${ }^{18}$ said that culture can influence behavior, then the ethnicity of each respondent is closely related to how the respondent applies treatment to patients. Ethnicity also influences a person's attitudes, behavior, and behavior, as in research Sidin ${ }^{19}$ explained that one of the most common ethnic groups in this study, namely the Bugis, has the values of matinulu (hard work), getteng (steadfast), macca (intelligent), deceng (good), assidengeng (unity), marenreng perru (faithful), and sipakatau (humanity).) which is expected to be able to support the value of providing quality nursing care.

\section{Islamic Spiritual Care}

Islamic spiritual care in its application consists of the ability to communicate according to Islamic law, remembering Allah through remembrance, encouraging patients to pray, instilling optimism that healing can be in Allah, and helping patients in worship.
${ }^{15}$ Kementerian Pemberdayaan Perempuan dan Perlindungan Anak, Profil Perempuan Indonesia 2019, Profil Perempuan Indonesia (Jakarta: Kementerian Pemberdayaan Perempuan dan Perlindungan Anak, 2019): 51-52.

${ }^{16}$ Hendy; Lesmana, Hasriana, dan Selvia Febrianti, "Analisis Komparatif Hasil Studi Mahasiswa Latar Belakang SMK dan SMA di Fakultas Ilmu Kesehatan Universitas Borneo Tarakan," Medisains 53, no. 9 (2016): 1689-99.

${ }^{17}$ Muh. Ikhsan Fadli Parawansah dan Junuda Nanlohy, La Rangki, "Pengaruh Pendekatan Transkultural
Nursing terhadap Prilaku Pengguna Pil Paracetamol, Cafein, dan Carisoprodol di Kota Kendari," Universitas Halu Oleo 1, no. 1 (2017): 508-14.

18 Parawansah dan Nanlohy, La Rangki.

${ }^{19}$ Andi Indahwaty Sidin, Yahya Thamrin, dan Rifa Mahmudah, "Pengaruh Lama Kerja terhadap Tingkat Organizational Citizenship Behavior (OCB) Perawat Suku Bugis di Instalasi Rawat Inap Rumah Sakit Labuang Baji The Effect Length of Work to the OCB Level of Bugis Tribe Nurses in the Inpatient Installation of Labuang," Jurnal MKMI 15, no. 3 (2019): 220-27. 
Table. 2 Application of Islamic Spiritual Care

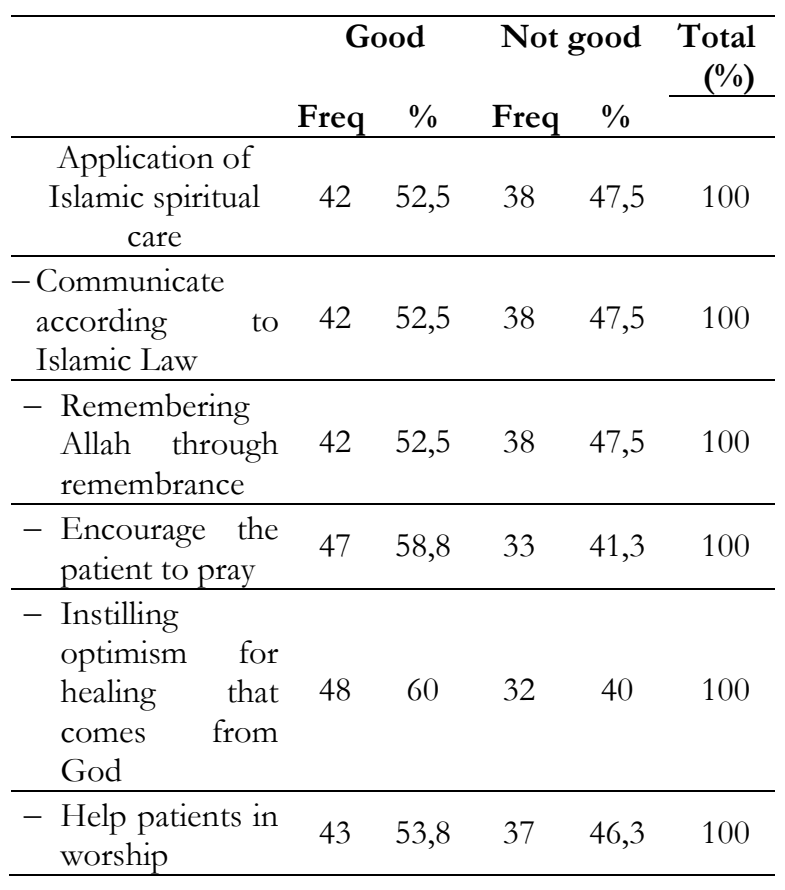

Table 2 shows that as many as 42 Nurse Profession student respondents who apply Islamic spiritual care are in the good category with a percentage of $52.5 \%$, while 38 respondents with a percentage of $47.5 \%$ are in the category of not applying Islamic spiritual care. In the component of communicating according to Islamic law, the number of respondents who applied it well was 42 respondents $(52.5 \%)$. In the component of remembering Allah through remembrance, the number of respondents who applied it well was 42 respondents $(52.5 \%)$.

In the component that encourages patients to pray, the number of respondents who apply it well is 47 respondents (58.8\%). In the component of instilling optimism for healing that comes from God, the number of respondents who apply it well is 48 respondents $(60 \%)$. In the component of helping patients in worship, the number of respondents who explained it well was 43 respondents (53.8\%)

The results showed that the application of Islamic spiritual care in 80 respondents of Nurse Profession students was found to be the majority making the application of Islamic spiritual care well as many as 42 respondents $(52.5 \%)$, only a slight difference with the results in the category of less in applying Islamic spiritual care as many as 47 respondents $47.5 \%$ ). However, it can still be concluded that applying Islamic spiritual care in this study is suitable.

Applying Islamic spiritual care is an important aspect to be fulfilled in patients. Wibawa $^{20}$ in his research explains that there is an influence on patients who are given a spiritual approach, at least on the level of knowledge and understanding of patients about their relationship with God, themselves and others related to their maladaptive behavior. Research conducted by Amiruddin ${ }^{21}$ that in applying spiritual nursing at the Barombong Health Center, 24 respondents $(80 \%)$ applied Islamic spirituality in the sufficient category. This is influenced by the spiritual aspects of nurses who are well fulfilled. The spiritual aspect of good respondents can be seen from how respondents undergo religious routines, especially routines in Islam such as obligatory prayers to sunnah, fasting, remembrance, alms, and being active or participating in organizations related to religion. ${ }^{22}$

There are many factors behind the application of spirituality to patients, especially in this study the results are almost said to be balanced between the application of good and bad student spiritual care. Novita ${ }^{23}$ explained
20 Zetty Wibawa dan Laili Nurhidayati, "Implementation of Inovation Meeting Spiritual Needs for Soul Disorders with Spiritual Care Method in RSJ Grhasia Jogyakarta," Journal of Chemical Information and Modeling 12, no. 1 (2020): 59-64.

21 Achmad Amiruddin dan Murniati Murniati, "Penerapan Aspek Spiritualitas dengan Pemenuhan Kebutuhan Spiritual pada Pasien," Jurnal Ilmiah Kesehatan
Sandi Husada 12, no. 2 (2020): 947-52, https://doi.org/10.35816/jiskh.v12i2.444.

22 Muhammad Mulyadi Pranata, Efri Widianti, dan Imas Rafiyah, "Kecerdasan Spiritual Mahasiswa Keperawatan Program Transfer," Journal of Nursing Care 3, no. 2 (2020): 80-85.

23 Novita; Estetika dan Noraliyatun Jannah, "Pelaksanaan Asuhan Keperawatan Spiritual di Suatu 
that two factors influence spiritual nursing care, namely intrinsic and extrinsic factors, where intrinsic factors are the inability of nurses to communicate, lack of knowledge about spirituality, personal matters, and fear of making mistakes. In contrast, extrinsic factors are organization and management, economic barriers in the form of lack of nurses, lack of time, and education. Mardiani ${ }^{24}$ The research also describes the factors that can influence the application of spiritual care to patients, these factors are awareness of self-spirituality, maintenance of self-spirituality, nurses are still confused about their role in providing spiritual care, and nurses do not understand spiritual needs and their benefits to patient health and healing.

Haris $^{25}$ explain the factors that can hinder the fulfillment of the patient's spiritual needs, namely the limited time in meeting the spiritual aspects of the patient, differences in culture and beliefs, the presence of clergy who according to nurses are their duty in fulfilling spiritual nursing care for patients. Azzahra ${ }^{26}$ explained that perception was the most influencing factor in providing spiritual care. Student perceptions of spiritual nursing are not good; this poor perception can be due to a lack of support from educational institutions to conduct learning about spiritual care both on campus and outside campus or during clinical practice.

It can be said that the good or the lack of application of Islamic spiritual care can be influenced by many factors, both intrinsic factors where Nurse students must improve communication well and increase spiritual aspects in themselves, then from extrinsic factors where education is an essential factor that affects knowledge. Students, especially Islamic spirituality, can be included in the Nurse's education curriculum.

Islam always sets a good example for its adherents, be it through the Qur'an, Sunnah, examples from the prophets and apostles, and the companions of the Prophet. The figure of nursing in Islam that needs to be emulated by Muslims is Rufaidah Al-Aslamiyah. Rufaidah was a companion who lived in the time of the Prophet saw who acted as a nurse both to take care of the sick in Medina and take care of war victims during the war during the time of the Prophet saw. Rufaidah's works in nursing include field hospitals, nursing schools, nurse ethics codes, nursing theory, and Islamic spiritual care. In Islamic spiritual care, the basis of Islamic spiritual care is the process of treatment, maintenance and spiritual development from all kinds of disorders and diseases that pollute the sanctity of spiritual nature so that they are safe and prosperous in the hereafter based on the demands of the Qur'an, sunnah, and the results of Ijtihad. ${ }^{27}$ As a health worker or prospective health worker, it is important to know the history and Islamic figures who play a role in the world of nursing to make them role models to become Islamic nurses and help the healing process of patients by involving Islamic aspects.

Kamali and the Ministry of Religion stated that students as prospective nurses must be
Rumah Sakit Banda Aceh," Jurnal Ilmiah Mahasiswa Fakultas Keperawatan 1, no. 1 (2016): 1-9.

${ }^{24}$ Hermansyah Mardiani, "Pemenuhan Kebutuhan Spiritual Care Pasien Rawat Inap," Jurnal Media Kesehatan 10, no. 1 (2017): 001-006, https://doi.org/10.33088/jmk.v10i1.316.

25 Fahni Haris dkk., "Pemenuhan Kebutuhan Spiritual Pasien Terpasang Alat Medis : Persepsi Pasien," Jurnal Keperawatan. Universitas Muhammadiyah Yogyakarta 12, no. 1 (2020): 79-84.

26 Azzahra, Nur, dan Kosasih, "Persepsi Mahasiswa Keperawatan tentang Perawatan Spiritual
(Spiritual Care) Perception of Nursing Students on Spiritual Care". Journal of Nursing Care \& Biomolecular 3, no. 2 (2018): 94-103. https://www.omazen.id/ojs/index.php?journal=JNC\&p age $=$ article\&op $=$ download\&path $\% 5 \mathrm{~B} \% 5 \mathrm{D}=108 \&$ path $\% 5 \mathrm{~B} \% 5 \mathrm{D}=129$

27 Abdul Hamid Saputra, Ading Kusdiana, dan Tolib Rahmatillah, "Rufaidah Al-Aslamiyah: Perawat Pertama di Dunia Islam (Abad 6-7 M.)," Historia Madania: Jurnal Ilmu Sejarah 4, no. 1 (2020): 1-30, https://doi.org/10.15575/hm.v4i1.9184. 
equipped with religious knowledge in providing spiritual needs to patients because when patients are sick, it is not only physical but there are spiritual aspects that are not paid attention to by health workers. Caring for patients is part of the nurse's morals, where Islam is present as rohmatallil'almiin. It is related to religious moderation. Religious moderation is an attitude of tolerance where nursing students are present to provide spiritual and not extreme care for their religion ${ }^{28 \& 29}$

\section{Application of Islamic Spiritual Care}

The application of Islamic spiritual care is divided into five components: communicating according to Islamic law, remembering Allah through remembrance, encouraging patients to pray, instilling optimism for healing from Allah, and helping patients in worship. According to Islamic law, the application of Islamic spiritual care to the communication component is included in the good category. This is in line with research conducted by Sasmito ${ }^{30}$ that the application of good communication to patients, the application of good therapeutic communication techniques is supported by the characteristics of nurses who are quite good and also because of the awareness of nurses in carrying out therapeutic communication, besides that motivation also affects nurses in implementing therapeutic communication because motivation is the driving factor for all behavior. The good communication applied by respondents following Islamic law can be seen from respondents who speak softly, in a low voice, are polite, friendly, always smiling, and say

${ }^{28}$ Kamali. M., H. The Middle Path of Moderation in Islam, The Qur'anic principle of Wasathiyah. (UK: Oxford University Press, 2015), 12-15.

${ }^{29}$ Kementrian Agama RI, Moderasi beragama. Moderasi. (Jakarta: Badan Litbang dan Diklat, 2019), 12

30 Priyo Sasmito dkk., "Penerapan Teknik Komunikasi Terapeutik oleh Perawat pada Pasien," Jurnal Kesehatan Poltekkes Ternate 11, no. 2 (2019): 58, https://doi.org/10.32763/juke.v11i2.87.

31 Nur Cahyo Sasongko dan Eni Hidayati, "Penerapan Terapi Musik, Dzikir dan Rational Emotive greetings. It is in line with communicating in Islam "qaul" as well as therapeutic communication that must be applied to patients.

Meanwhile, applying Islamic spiritual nursing based on the category of remembering Allah through remembrance found respondents who applied it well. It shows that respondents are good at implementing remembrance and recommending patients to do remembrance. Sasongko ${ }^{31}$ in the study of the application of remembrance to patients at risk of violent behavior, it was found that remembrance affected reducing the anger threshold of patients with violent risk behavior. In addition, remembrance can reduce depression in patients with kidney failure who are undergoing hemodialysis, it is found that there is a decrease in depression levels. It explains that remembering Allah through remembrance has a positive value for both the respondent and the patient.

The application of Islamic spirituality by category encourages patients to pray and apply it well. Encouraging patients to pray or called prayer therapy is also applied in Rahmawati's research ${ }^{32}$ where the results of the research show that by praying for preoperative cesarean section patients, it is found that there is a decrease in anxiety in these patients; praying and remembrance can focus thoughts aimed at the Creator. Centralized thinking will stabilize the body's neurotransmitters; information from the periphery is needed not only to respond to environmental changes but also to inhibit the continuation of neuroendocrine processes. Prasetyo $^{33}$ explained that prayer is believed to

Cognitive Behavior Therapy pada Pasien dengan Resiko Perilaku Kekerasan,” Ners Muda 1, no. 2 (2020): 93, https://doi.org/10.26714/nm.v1i2.5751.

32 Rita Rahmawati dan Aliyatul Muhimmi, "Spiritual Care Membaca Doa dan Dzikir terhadap Kecemasan Pasien Pre Operasi Seksio Sesarea," Journals of Ners Community 07 (2016): 77-84.

${ }^{33}$ Agus Prasetyo, "Aspek Spiritualitas Sebagai Elemen Penting dalam Kesehatan," Jurnal Kesehatan AlIrsyad IX, no. 1 (2016): 28-34. 
provide calm and relaxation situations; the relaxation is obtained from 2 simple procedures: repeating a word, phrase or muscle activity and eliminating disturbing thoughts in mind. When these two activities are carried out regularly, they produce good physiological effects and can be therapeutic in several medical conditions.

Another component of applying Islamic spiritual nursing is to instill optimism for healing that comes from Allah. Respondents who apply this component in the good category with a fairly far comparison with those who apply it less. This component is the component that most respondents apply well. Sabrini ${ }^{34}$ explained that optimism for healing comes from spiritual aspects that must be fulfilled, this spiritual aspect itself can be carried out well by patients if the motivation carried out by nurses is also good, spiritual motivations that can be done such as faith motivation, worship motivation, and muamalah motivation, where faith motivation is It's like believing in God with all my heart that God is God who can give pain and healing to his servants.

Nurse students help patients in worship in good category. Azizah ${ }^{35}$ in his research explained that nurses who remind patients of prayer times and remind them to perform ablution, the number of patients who perform prayers is more than if nurses do not remind, this illustrates the importance and need for nurses and students who are practicing in hospitals to remind and help patients perform prayers in order to fulfill the patient's spiritual needs.

The good application of Islamic spiritual components has a good impact on patients, fulfilled Islamic spirituality can support the patient's healing process. Therefore, it is crucial for health agencies, especially hospitals, to pay attention to the application of Islamic spiritual

34 Sibrini dan Nur Azizah, "Motivasi dan Bimbingan Spiritual untuk Sembuh Pada Penderita Stroke" 3, no. 2 (2021): 79-89. care and increase the competence of health workers to be able to apply spiritual care to patients.

\section{Conclusion}

Nurse students apply Islamic spiritual care to patients well. The application of all components of Islamic spiritual care, namely communicating according to Islamic law, remembering Allah through remembrance, encouraging patients to pray, instilling optimism for healing that comes from Allah, and helping patients in worship, are also well implemented. Nurse students dominantly apply the optimism of healing that comes from God to be the component best applied by Nurse students when providing Islamic spiritual care to patients.

Nurse students are expected to pay attention to and improve their spiritual aspects continue to be improved by doing worship, both obligatory and sunnah in Islam, such as praying, dhikr, reading the Qur'an, fasting, giving charity. It is hoped that the reflection of this spiritual application in the Nursing Profession students will become accustomed and apply Islamic spiritual care to patients. The results of this study can be used as basic data for the application of spiritual care to nursing students so that they can be included in the development of nursing study programs, for example in learning guidelines, guidance processes and clinical learning achievement targets in order to increase the ability of Islamic spiritual competence of nursing students so that they become competent Muslim nurses. Further research can deepen research related to Islamic spiritual care for nursing students through qualitative methods and influencing factors.

\section{References}

Ahmadiansah, Reza. "Model Dakwah dalam Pelayanan Pasien." IJIP : Indonesian Journal

${ }^{35}$ Noor Azizah dan Muhammad Purnomo, "Pelaksanaan Wudhu Tayamum dan Sholat Pasien di Rumah Sakit," Jurnal Ilmu Keperawatan dan Kebidanan 10, no. 2 (2019): 303, https://doi.org/10.26751/jikk.v10i2.657. 
of Islamic Psychology 1, no. 2 (2019): 215-42. https://doi.org/10.18326/ijip.v1i2.215242.

Amiruddin, Achmad, dan Murniati Murniati. "Penerapan Aspek Spiritualitas dengan Pemenuhan Kebutuhan Spiritual Pada Pasien." Jurnal Ilmiah Kesehatan Sandi Husada 12, no. 2 (2020): 947-52. https://doi.org/10.35816/jiskh.v12i2.44 4.

Anggoro, Wisnu Tri, Qurrotul Aeni, dan Istioningsih Istioningsih. "Hubungan Karakteristik Perawat dengan Perilaku Caring." Jurnal Keperawatan Jiwa 6, no. 2 (2019):

98. https://doi.org/10.26714/jkj.6.2.2018.98 -105 .

Annisa, Elsa, Herman, dan Yoga Pramana. "Kebutuhan Spiritual dengan Kulitas Hidup Pada Lanjut Usia: Literature Review." Jurnal ProNers, no. July (2021): 1-12.

Azizah, Noor, dan Muhammad Purnomo. "Pelaksanaan Wudhu Tayamum dan Sholat Pasien di Rumah Sakit." Jurnal Ilmu Keperawatan dan Kebidanan 10, no. 2 (2019): 303. https://doi.org/10.26751/jikk.v10i2.657.

Azzahra, Meza Belindiani, Aan Nur, dan Cecep Eli Kosasih. "Persepsi Mahasiswa Keperawatan Tentang Perawatan Spiritual ( Spiritual Care ) Perception of Nursing Students on Spiritual Care." Nursing Care \& Biomelecular 3, no. 2 (2018): 94-103. https://www.omazen.id/ojs/index.php?j ournal $=J$ NC\&page $=$ article $\& o p=$ downlo ad\&path $\% 5 \mathrm{~B} \% 5 \mathrm{D}=108 \&$ path $\% 5 \mathrm{~B} \% 5 \mathrm{D}$ $=129$

Bawelle, Selleya Cintya, Sinolungan, dan Rivelino S Hamel. "Hubungan Pengetahuan dan Sikap Perawat dengan Pelaksanaaan Keselamatan Pasien (Patient Safety) di Ruang Rawat Inap Rsud Liun Kendage Tahuna." Jurnal Keperawatan UNSRAT 1, no. 1 (2013): 113221.

Estetika, Novita;, dan Noraliyatun Jannah. "Pelaksanaan Asuhan Keperawatan Spiritual di Suatu Rumah Sakit Banda
Aceh." Jurnal Ilmiah Mahasiswa Fakultas Keperawatan 1, no. 1 (2016): 1-9.

Febrianti, Reni, Yulastri Arif, dan Mira Susanti. "Faktor yang Mempengaruhi Peran Perawat dalam Memenuhi Kebutuhan Spiritual Pasien." Jurnal Ilmiah Ilmu Kesehatan 6, no. 1 (2020): 282-90.

Haris, Fahni, Yanti Auliyantika, Fajar Bagus Putra, Wahyuni Jannatin Aliyah, dan Muhammad Afandi. "Pemenuhan Kebutuhan Spiritual Pasien Terpasang Alat Medis: Persepsi Pasien." Jurnal Keperawatan. Universitas Mubammadiyah Yogyakarta 12, no. 1 (2020): 79-84.

Kamali. Muhammad, Hasyim. The Middle Path of Moderation in Islam, The Qur'anic principle of Wasathiyah. UK: Oxford University Press, 2015.

Kementrian Agama RI. Moderasi beragama. Moderasi. Jakarta: Badan Litbang dan Diklat, 2019.

Kementerian Kesehatan RI. "Situasi Tenaga Keperawatan Indonesia." Pusat Data dan Informasi Kementerian Kesehatan RI, 2017. https://pusdatin.kemkes.go.id/folder/vi ew/01/structure-publikasi-pusdatin-infodatin.html.

Kementerian Pemberdayaan Perempuan dan Perlindungan Anak. Profil Perempuan Indonesia 2019. Profil Perempuan Indonesia. Jakarta: Kementerian Pemberdayaan Perempuan dan Perlindungan Anak, 2019.

Lesmana, Hendy; Hasriana, dan Selvia Febrianti. "Analisis Komparatif Hasil Studi Mahasiswa Latar Belakang SMK dan SMA di Fakultas Ilmu Kesehatan Universitas Borneo Tarakan." Medisains 53, no. 9 (2016): 1689-99. http://dx.doi.org/10.30595/medisains.v $14 \mathrm{i} 1.1042$

Mardiani, Hermansyah. "Pemenuhan Kebutuhan Spiritual Care Pasien Rawat Inap." Jurnal Media Kesehatan 10, no. 1 (2017): 001-006. https://doi.org/10.33088/jmk.v10i1.316.

Parawansah, Muh. Ikhsan Fadli, dan Junuda Nanlohy, La Rangki. "Pengaruh 
Pendekatan Transkultural Nursing Terhadap Prilaku Pengguna Pil Paracetamol, Cafein, dan Carisoprodol di Kota Kendari." Universitas Halu Oleo 1, no. 1 (2017): 508-14. ISSBN : 978-602-71928$1-2$

Pesut, Barbaba. Spirituality and Spiritual Care in Nursing Fundamentals Textbooks. J Nurs $E d u$ 47, no. 4 (2008):167-73. doi: 10.3928/01484834-20080401-05.

https://pubmed.ncbi.nlm.nih.gov/18468 $293 /$.

PPNI. Standar Diagnosa Keperawatan Indonesia: Definisi dan Indikator Diagnostik, 2016.

Pranata, Muhammad Mulyadi, Efri Widianti, dan Imas Rafiyah. "Kecerdasan Spiritual Mahasiswa Keperawatan Program Transfer." Journal of Nursing Care 3, no. 2 (2020): 80-85.

Prasetyo, Agus. "Aspek Spiritualitas Sebagai Elemen Penting dalam Kesehatan." Jurnal Kesehatan Al-Irsyad 9, no. 1 (2016): 28-34.

Purwaningsih, Diah Fitri. "Perilaku Caring Perawat di Ruang Rawat Inap." Jurnal Ilmiah Kesehatan 3, no. 2 (2018):12.

Rahmawati, Rita, dan Aliyatul Muhimmi. "Spiritual Care Membaca Doa dan Dzikir terhadap Kecemasan Pasien Pre Operasi Seksio Sesarea." Journals of Ners Community 07 (2016): 77-84.

Ross, Linda, Wilfred McSherry, Tove Giske, René van Leeuwen, Annemiek SchepAkkerman, Tiburtius Koslander, Jenny Hall, Vibeke Østergaard Steenfeldt, dan Paul Jarvis. "Nursing and Midwifery Students' Perceptions of Spirituality, Spiritual Care, and Spiritual Care Competency: A Prospective, Longitudinal, Correlational European Study." Nurse Education Today 67, no. April (2018): 64 71.https://doi.org/10.1016/j.nedt.2018.0 5.002 .

Saharuddin, Safrullah Amir, dan Rosmina. "Penrapan Pelayanan Model Keperawatan Berbasis Spiritual Ditinjau dari Aspek Proses Asuhan Keperawatan Spiritual di Rumah Sakit Islam Faisal
Makassar." Hospital Majapabit 10, no. 1 (2018): 28-33.

Saputra, Abdul Hamid, Ading Kusdiana, dan Tolib Rahmatillah. "Rufaidah AlAslamiyah: Perawat Pertama di Dunia Islam (Abad 6-7 M.)." Historia Madania: Jurnal Ilmu Sejarah 4, no. 1 (2020): 1-30. https://doi.org/10.15575/hm.v4i1.9184.

Sasmito, Priyo, Majadanlipah Majadanlipah, Raihan Raihan, dan Ernawati Ernawati. "Penerapan Teknik Komunikasi Terapeutik oleh Perawat pada Pasien." Jurnal Kesehatan Poltekkes Ternate 11, no. 2 (2019):

58. https://doi.org/10.32763/juke.v11i2.87.

Sasongko, Nur Cahyo, dan Eni Hidayati. "Penerapan Terapi Musik, Dzikir dan Rational Emotive Cognitive Behavior Therapy pada Pasien dengan Resiko Perilaku Kekerasan." Ners Muda 1, no. 2 (2020): https://doi.org/10.26714/nm.v1i2.5751.

Sibrini, dan Nur Azizah. "Motivasi dan Bimbingan Spiritual untuk Sembuh Pada Penderita Stroke" 3, no. 2 (2021): 79-89.

Sidin, Andi Indahwaty, Yahya Thamrin, dan Rifa Mahmudah. "Pengaruh Lama Kerja terhadap Tingkat Organizational Citizenship Behavior (OCB) Perawat Suku Bugis di Instalasi Rawat Inap Rumah Sakit Labuang Baji The Effect Length of Work to the OCB Level of Bugis Tribe Nurses in the Inpatient Installation of Labuang." Jurnal MKMI 15, no. 3 (2019): 220-27.

Talibo, Norman Alfiat, Tri Kurniati, dan Giri Widakdo. "Penerapan Bentuk Perilaku Islami terhadap Kemampuan Perawat Mengimplementasi Asuhan Keperawatan Islami di Ruang Rawat Inap." Journal of Telenursing (JOTING) 1, no. 2 (2019): 32433.

Wardah, Rizka Febtriana, dan Eka Dewi. "Pengaruh Pengetahuan Perawat terhadap Pemenuhan Perawatan Spiritual Pasien di Ruang Intensif." Jurnal Endurance 2, no. October (2017): 436-43. 
Wibawa, Zetty, dan Laili Nurhidayati. Yoost, Barbara L, dan Lynne R Crawford. "Implementation of Inovation Meeting Spiritual Needs for Soul Disorders With Fundamental of Nursing: Active Learning for Collaboratibe Practice. St. Louis Missouri: Spiritual Care Method in RSJ Grhasia Elsevier, 2016.

Jogyakarta." Journal of Chemical Information and Modeling 12, no. 1 (2020): 59-64. 